\title{
ANTIOXIDANT AND ANTICANCER POTENTIAL OF Neolamarckia cadamba (ROXB.) BARK EXTRACT
}

\section{Vishal Khandelwal*, Pradeep Kumar Choudhary}

Department of Biotechnology, GLA University, Mathura-281406, India

Received - March 14, 2020; Revision - May 19, 2020; Accepted - June 01, 2020

Available Online - June 25, 2020

DOI: http://dx.doi.org/10.18006/2020.8(3).334.338

\author{
KEYWORDS \\ N. cadamba \\ DPPH \\ Sulforhodamine \\ N1S1 rat hepatoma cell line
}

\begin{abstract}
Current study was conducted to screen the antioxidant and anti cancerous potential of Hydro-methanolic (HM) bark extract of Neolamarckia cadamba. Further presence of various phytochemicals in HM extract of $N$. cadamba was also accessed by using suitable phytochemical tests. Result of current study suggested the presence of alkaloids, steroids, glycosides, triterpenoids, carbohydrates, flavonoids, tannins and phenols where as the presence of protein and amino acids was not reported in the HM extract of N. cadamba. In vitro antioxidant potential of different doses i.e. $0.025,0.05,0.1$ and $0.2 \mathrm{mg} / \mathrm{ml}$ of $N$. cadamba HM bark extract were determined using DPPH free radical scavenging method. Results showed significant $(\mathrm{p}<0.01)$ antioxidant efficacy of $0.025,0.05$ and $0.1 \mathrm{mg} / \mathrm{ml}$ doses of extract when compared with standard treatment. Evaluation of anticancer activity of different concentrations $(10,20,40$ and $80 \mu \mathrm{g} / \mathrm{ml})$ of $\mathrm{HM}$ extract was done against N1S1 rat hepatoma cancerous cell line using sulforhodamine (SRB) assay. Percentage of control cell growth was -37.66 and -34.13 at $40 \mu \mathrm{g} / \mathrm{ml}$ and $80 \mu \mathrm{g} / \mathrm{ml}$ respectively. Dose dependent decrease in percentage of control cell growth was observed. LC50, TGI and GI50 of HM extract was found to be $75.92,46.73$ and $17.46 \mu \mathrm{g} / \mathrm{ml}$ respectively. Present study concludes in vitro antioxidant and anticancerous potential of HM extract of $N$. cadamba bark.
\end{abstract}

* Corresponding author

E-mail: vishal_k80@rediffmail.com (Vishal Khandelwal)

Peer review under responsibility of Journal of Experimental Biology and Agricultural Sciences.

Production and Hosting by Horizon Publisher India [HPI] (http://www.horizonpublisherindia.in/).

All rights reserved.
All the articles published by Journal of Experimental Biology and Agricultural Sciences are licensed under a Creative Commons Attribution-NonCommercial 4.0 International License Based on a work at www.jebas.org.

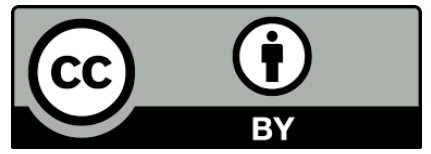




\section{Introduction}

Neolamarckia cadamba synonyms Kadam, native to South Asia and South East Asia (Krisnawati et al., 2011). The Charaka Samhita and Sushruta Samhita narrates the ethnomedicinal uses of $N$. cadamba bark as an analgesic, for strengthening body, against snake bite, diarrhea, dysentery, leucorrhoea and spermatorrhoea (Sircar, 1992; Slkar et al., 1992). Further, various parts of $N$. cadamba i.e. leaf, bark, fruit and flower has been traditionally used by many tribes and communities in India against fever, cough, sour throat, infections and inflammation (Pandey \& Negi, 2016). Phytochemical analysis of different parts of $N$. cadamba detects the presence of chlorogenic acid, $\beta$-sitosterol, indole alkaloids and cadambine which shows anti-inflammatory, antimutagenic, antipyretic, antidiabetic, antidiarrheal and antioxidant activities (Gupta et al., 1980; Li \& Chang, 2005; Alam et al., 2008; Kumar et al., 2015a; Verma et al., 2019; Mondal et al., 2020).

Methanolic extract of $N$. cadamba bark contains number of secondary metabolites such as cadambagenic acid, saponin B, Glycosides A \& B, Phelasin A \& B and 3 $\beta$-dihydrocadambine (Sahu et al., 1999; Sahu et al., 2000; Chandel et al., 2011). Presence of phenolics compounds, alkaloids and saponins in different extracts of $N$. cadamba bark attributes to its antimicrobial, antidiabetic, antiepileptic activity (Gurjar et al., 2010; Patel et al., 2011; Nagakannan et al., 2011). Chronic persistence of free radicals (reactive oxygen species; ROS and reactive nitrogen species; RNS) lead to oxidative stress, responsible for disorders related to nervous system, metabolic disorders like diabetes mellitus and several form of cancers (Huy et al., 2008). Traditionally bark of $N$. cadamba has been used against inflammation, fever, cough and wound. To scientifically validate ethno-medicinal uses of bark of $N$. cadamba, present study has been designed to determine in vitro antioxidant and anticancer efficacy of hydromethanolic (HM) extract of $N$. cadamba bark.

\section{Materials and Methods}

\subsection{Used chemicals and cell line used Experimental animals}

2,2-diphenyl-1-picrylhydrazyl (DPPH), ascorbic acid, butylated hydroxyl toluene (BHT), RPMI-1640 medium, sulforhodamine (SRB) and TCA were procured from Sigma Aldrich, USA. N1S1 rat hepatoma cancerous cell line was obtained from Tata Memorial centre, Mumbai.

\subsection{Plant material}

Neolamarckia cadmba bark was collected from Mathura and Vrindavan areas of Uttar Pradesh, India. Plant was identified and authenticate by Dr A S Updadhye, Agharkar Research Institute, Pune with voucher deposition No. L-084. Dried bark powder of $N$. cadamba was used in preparation of hydo-methanolic (HM) extract.

\subsection{Extract Preparation}

Dried powder of $N$. cadamba bark was subjected to soxhlet extraction. Hydro-methanolic $(80: 20, \mathrm{v} / \mathrm{v})$ solvent was allowed to boil at $65^{\circ} \mathrm{C}$ for $7-8 \mathrm{hrs}$. Solvent was evaporated at temperature and reduced pressure using rotary evaporator. Lastly dark brown crystals were obtained and used in further studies.

\subsection{Preliminary Phytochemical analysis of HM extract of $N$. cadamba bark}

Qualitative analysis of hydro-methanolic extract of $N$. cadamba bark was done as per standard protocol (Debela, 2002). HM extract of $N$. cadamba bark were subjected to preliminary phytochemical screening to detect the presence of steroids, triterpenoids, glycosides, carbohydrates, alkaloids, flavonoids, tannins, phenolics, proteins, amino acids, gum, mucilages, fats and oils.

\subsection{Evaluation of in vitro antioxidant potential of HM extract of $N$. cadamba bark}

In vitro antioxidant activity of HM extract of $N$. cadamba bark was evaluated by 2,2-diphenyl-1-picryl hydrazyl (DPPH) free radical scavenging assay method (Blois, 1958). Different concentrations $(0.025 \mathrm{mg} / \mathrm{ml}, 0.05 \mathrm{mg} / \mathrm{ml}, 0.1 \mathrm{mg} / \mathrm{ml}$ and $0.2 \mathrm{mg} / \mathrm{ml})$ of $\mathrm{HM}$ extract of $N$. cadamba bark were used for antioxidant activity. From various concentrations, $0.1 \mathrm{ml} \mathrm{HM}$ extract were mixed with $3.0 \mathrm{ml}$ of DPPH $(0.1 \mathrm{mM})$. Mixture was incubated at $20^{\circ} \mathrm{C}$ for 40 minutes in dark. Optical density (OD) was determined at $517 \mathrm{~nm}$ with ethanol and water (1:1) as blank. Readings were taken in triplicate. Determination of percentage inhibition of DPPH was calculated by using formula given by Gulcin et al., (2005).

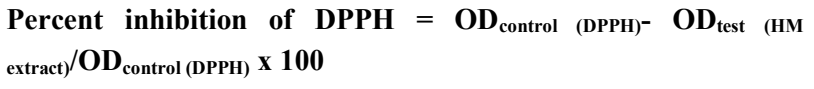

Standard used were butylated hydroxyl toluene (BHT) and ascorbic acid were used as standards.

\subsection{In vitro anticancer activity of $\mathrm{HM}$ extract of $N$. cadamba bark}

Determination of in vitro anticancer activity of HM extract of $N$. cadamba bark was carried out at Tata Memorial centre, Mumbai using N1S1 rat hepatoma cell line according to standard procedure (Vichai \& Kirtikara, 2006). Cell suspension $(100 \mu \mathrm{L})$ in triplet was inoculated in 96 well microtiter plate. Plate was incubated at $37^{\circ} \mathrm{C}$ in $\mathrm{CO}_{2}$ incubator $\left(5 \% \mathrm{CO}_{2} \& 100 \% \mathrm{RH}\right)$ for $24 \mathrm{hrs}$. Different doses $(10,20,40 \& 80 \mu \mathrm{g} / \mathrm{ml})$ of $\mathrm{HM}$ extract and Adriamycin (standard) were added into wells of microtiter plate. Plate was 
again allowed to incubate at $37^{\circ} \mathrm{C}$ for 48 hours in $\mathrm{CO}_{2}$ incubator. Termination of reaction was done by adding $30 \%$ chilled TCA. This was followed by staining of cells by adding $0.4 \%$ sulforhodamine (SRB) in $1 \%$ acetic acid solution. Elution of SRB dye bounded to cell protein was carried out by adding Tris base. Absorbance was measured at $510 \mathrm{~nm}$ by ELISA reader.

Percent growth $=$ Mean absorbance test/Mean absorbance control $\times 100$

Percent of control cell growth $=\frac{\begin{array}{c}\text { Mean absorbance sample } \\ \text { mean absorbance day } 0 \times 100\end{array}}{\begin{array}{c}\text { Mean absorbance neg control } \\ - \text { mean absorbance day } 0\end{array}}$

Percent growth inhibition $=100-\%$ of control cell growth

Percent cell killed $=100-$ mean absorbance sample $/$ mean absorbance day $0 \times 100$

\subsection{Statistical analysis}

Data analysis was done using one way analysis of variance (ANOVA) using SPSS version 20.0 software and DMRT at $\mathrm{p}<$ 0.01 to determine significant differences among treated means. Values are expressed as mean $\pm \mathrm{SEM}$.

\section{Results and Discussion}

Percentage yield of $N$. cadamba HM extract was reported 14 percent. Results of preliminary phytochemical analysis revealed the presence of alkaloids, steroids, glycosides, triterpenoids, carbohydrates, flavonoids, tannins, phenols, fats, oils, gums, mucilage's where as proteins and amino acids were absent (Table 1). Presence of these secondary metabolites cause inhibition of microbial growth (Negi, 2012) and does offer various ethnomedicinal uses of $N$. cadamba bark (Pandey \& Negi, 2016).

Present study concerns with evaluation of in vitro antioxidant potential of $N$. cadamba bark extract. DPPH free radical scavenging method was used to determine percentage inhibition of free radicals in presence of $0.025,0.050,0.1$ and $0.2 \mathrm{mg} / \mathrm{ml} \mathrm{HM}$ extract of $N$. cadamba bark. Results of study suggested significant $(\mathrm{p}<0.01)$ antioxidant efficacy of $N$. cadamba bark extract at different doses, when compared with ascorbic acid and BHT (Table 2).

Maximum percentage inhibition was reported at $0.20 \mathrm{mg} / \mathrm{ml} \mathrm{HM}$ extract. Dose dependent inhibition of free radical scavenging activity was found. Result of current study are in agreement with previous findings, suggesting the presence of phenolics compounds in bark extract might caused scavenging of free radicals (Chandel et al., 2011). Antioxidant compounds counter free radicals mediate oxidative stress in the cell (Blokhina et al., 2003; Mondal et al.,
Table 1 Phtochemical screening of HM extract of $N$. cadamba bark

\begin{tabular}{|cccc|}
\hline SN & Phytochemical & Test Name & Inference \\
\hline 1 & Alkaloids & $\begin{array}{c}\text { Mayer's, Hager's and } \\
\text { Wagner's }\end{array}$ & + \\
\hline 2 & Steroids & $\begin{array}{c}\text { Salkowski's and Liberman } \\
\text { Burchard's }\end{array}$ & + \\
\hline 3 & Glycosides & Legal's and Borntrager & + \\
\hline 4 & Triterpenoids & Salkowski's & + \\
\hline 5 & Carbohydrates & Molisch's & + \\
\hline 6 & $\begin{array}{c}\text { Proteins and } \\
\text { amino acids }\end{array}$ & Ninhydrin & - \\
\hline 7 & Flavonoids & $\begin{array}{c}\text { Shinoda and Alkaline } \\
\text { reagent }\end{array}$ & + \\
\hline 8 & $\begin{array}{c}\text { Tannins and } \\
\text { Phenols }\end{array}$ & $\begin{array}{c}5 \% \text { FeCl } 3 \text { and Bromine } \\
\text { water }\end{array}$ & + \\
\hline 9 & Fats and oils & Saponification & + \\
\hline 10 & $\begin{array}{c}\text { Gum and } \\
\text { Mucilage's }\end{array}$ & \begin{tabular}{c} 
Ruthenium red \\
\hline
\end{tabular} & + \\
\hline
\end{tabular}

+ sign indicates present and - sign indicates absent

Table 2 Percentage inhibition of free radicals in presence of different concentrations of HM extracts, Ascorbic acid and BHT

\begin{tabular}{|cccc|c|}
\hline S.N & $\begin{array}{c}\text { Concentration } \\
(\mathrm{mg} / \mathrm{ml})\end{array}$ & HM extract & $\begin{array}{c}\text { Ascorbic acid } \\
(\text { Standard) }\end{array}$ & BHT (Standard) \\
\hline 1 & 0.025 & $71.21^{\mathrm{c}} \pm 0.96$ & $12.56^{\mathrm{a}} \pm 0.16$ & $19.72^{\mathrm{b}} \pm 0.71$ \\
\hline II & 0.050 & $78.86^{\mathrm{c}} \pm 1.02$ & $24.31^{\mathrm{a}} \pm 0.97$ & $43.25^{\mathrm{b}} \pm 0.16$ \\
\hline III & 0.10 & $82.73^{\mathrm{c}} \pm 1.05$ & $42.82^{\mathrm{a}} \pm 0.30$ & $55.74^{\mathrm{b}} \pm 1.07$ \\
\hline IV & 0.20 & $84.13^{\mathrm{b}} \pm 0.95$ & $93.37^{\mathrm{c}} \pm 0.02$ & $75.88^{\mathrm{a}} \pm 0.80$ \\
\hline
\end{tabular}

Values represent mean \pm SEM of triplet experiment. Results are significant at $p<0.01$

2020). Present study also revealed the presence of phenols during phytochemical screening of $N$. cadamba bark, which might probably responsible for its significant antioxidant activity. Result of current study can be concluded that HM extract of $N$. cadamba is good enough to overcome oxidative stress and serves as therapeutic agents for treating radical related pathological damage.

Four concentrations $(10,20,40$ and $80 \mu \mathrm{g} / \mathrm{ml})$ of HM extract of $N$. cadamba bark were screened using N1S1 rat hepatoma cell line. Adriamycin was used as standard cytotoxic agent. Different concentrations of HM extract of $N$. cadamba bark were found to be effective against N1S1 rat hepatoma cell line (Table-3). Dose dependent decrease in percentage cell growth of rat hepatoma was reported in current study. LC50, TGI and GI50 of HM extract was reported 75.92, 46.73 and $17.46 \mu \mathrm{g} / \mathrm{ml}$ respectively (Table 4). Previous studies also suggested cytotoxic activity of $N$. cadamba against different human cancer cell lines (Singh et al., 2013; 
Table-3 Effect of different concentrations of HM extracts against

$\%$ Cell growth of N1S1 rat hepatoma cell line

\begin{tabular}{|c|c|c|c|c|c|}
\hline \multicolumn{6}{|c|}{$\%$ Control Growth of rat hepatoma cell line N1S1 } \\
\hline S.N & Extract/Drug & $\begin{array}{c}10 \\
\mu \mathrm{g} / \mathrm{ml}\end{array}$ & $\begin{array}{c}20 \\
\mu \mathrm{g} / \mathrm{ml}\end{array}$ & $\begin{array}{c}40 \\
\mu \mathrm{g} / \mathrm{ml}\end{array}$ & $\begin{array}{c}80 \\
\mu \mathrm{g} / \mathrm{ml}\end{array}$ \\
\hline 1 . & HM extract & 90.50 & 48.06 & -37.66 & -34.13 \\
\hline 2. & $\begin{array}{c}\text { ADR } \\
\text { (Adriamycin) }\end{array}$ & -14.21 & -31.84 & -46.75 & -17.92 \\
\hline
\end{tabular}

Table 4 LC50, TGI and GI50 of HM extract and ADR

\section{Rat hepatoma Cell} line N1S1

Drug Concentrations $(\mu \mathrm{g} / \mathrm{ml})$

\begin{tabular}{|c|c|c|c|}
\hline N1S1 & LC50 & TGI & GI50 \\
\hline HM extract & 75.92 & 46.73 & 17.46 \\
\hline ADR & NE & $<10$ & $<10$ \\
\hline
\end{tabular}

LC50 - concentration of drug causing 50\% cell kill; TGI - concentration of drug causing total inhibition of cell growth; GI50 - concentration of drug causing 50\% inhibition of cell growth; ADR - adriamycin standard, HM extract - hydromethanolic extract

Kumar et al., 2015b; Dolai et al., 2016). Current study depicts the presence of phenolic compounds in HM extract of $N$. cadamba bark, responsible for antiproliferative activity (Fatima et al., 2016).

\section{Conclusion}

Present study concluded significant antioxidant activity of different doses of HM extract of $N$. cadamba bark. Study also revealed anticancer efficacy of bark extract. There is a need to isolate and molecular characterization of active ingredients present in hydromethanolic extract of $N$. cadamba bark.

\section{Acknowledgements}

We are thankful to Director, Institute of Applied Sciences and Humanities, GLA University, Mathura for providing necessary facility.

\section{Conflicts of Interest}

The authors declare that there is no conflict of interest.

\section{Author's contribution}

Vishal Khandelwal and Pradeep Kumar Choudhary contributed significantly and equally.

ORCID ID Vishal Khandelwal: 0000-0003-4321-8125

ORCID ID Pradeep Kumar Choudhary: 0000-0003-4816-455X

\section{Funding}

None.

\section{Data Availability}

All datasets generated or analyzed during this study are included in the manuscript.

\section{Ethics Statement}

Ethical clearance was obtained with IAEC approval vide GLAIPR/CPCSEA/IAEC/2014/Biotech/02.

\section{References}

Alam MA, Akter R, Subhan N, Rahman MM, Majumder MM, Nahar, Sarker SD (2008) Antidiarrhoeal property of the hydroethanolic extract of the Fruits of Anthocephalus cadamba. Revista Brasileira de Farmacognosia 18: 155-159.

Blois MS (1958) Antioxidant determinations by the use of a stable free radical. Nature 26: 1199-1200.

Blokhina O, Virolainen E, Fagerstedt KV (2003) Antioxidant, oxidative damage and oxygen deprivation: a review. Annals of Botany 91: 179-194.

Chandel M, Kaur S, Kumar S (2011) Studies on the genoprotective/antioxidant potential of methanol extract of Anthocephalus cadamba (Roxb.) Miq. Journal of Medicinal Plants Research 5: 4764-4770.

Debela A (2002) Manual for Phytochemical Screening of Medicinal Plants, Addis Ababa: Ethiopian Health and Nutrition Research Institute, Ethiopia, 35-47.

Dolai N, Islam A, Haldar PK (2016) Methanolic extract of Anthocephalus cadamba induces apoptosis in Ehrlich ascites carcinoma cells in experimental mice. Indian Journal of Pharmacology 48: 445-459

Fatima N, Ahmad MK, Ansari JA, Khan HJ, Rastogi N, Srivastava SK, Ahmad S, Ali Z (2016) Antiproliferative and antioxidant studies of Anthocephalus cadamba Rox. Miq. Bark. Indian Journal of Pharmaceutical Sciences 78: 525-531.

Gulcin I, Beydemir S, Sat IG, Kufrevioglu OI (2005) Evaluation of antioxidant activity of cornelian cherry (Cornus mas L.). Acta Aliment Hung 34: 193-202.

Gupta MB, Nath R, Srivastava N, Shanker K, Kishor K, Bhargava KP (1980) Antiinflammatory and Antipyretic Activities of $\beta$ Sitosterol. Planta Medica 39: 157-163.

Gurjar H, Jain SK, Irchhaiya R, Nandanwar R, Sahu VK, Saraf H (2010) Hypoglycemic effects of methanolic extract of Anthocephalus cadamba

Journal of Experimental Biology and Agricultural Sciences http://www.jebas.org 
bark in alloxan induced diabetic rats (Rox B) Miq. International Journal of Pharmaceutical Sciences and Research 1: 79-83.

Huy LAP, He H, Huy CP (2008) Free radicals, antioxidant in disease and health. International Journal of Biomedical Science 4: 89-96.

Krisnawati H, Kallio MH, Kanninen M (2011) Anthocephalus cadamba Miq.: Ecology, silviculture and productivity. CIFOR.

Kumar A, Chowdhury SR, Jatte KK, Chakrabarti T, Majumder HK, Jha T, Mukhopadhyay S (2015a) Anthocephaline, a new indole alkaloid and cadambine, a potent inhibitor of DNA topoisomerase IB of Leishmania donovani (LdTOP1LS), isolated from Anthocephalus cadamba. Natural Product Communications 10: 297-299.

Kumar D, Tejaswi C, Rasamalla S, Mallick S, Pal BC (2015b) Bio-assay guided isolation of anti-cancer compounds from Anthocephalus cadamba bark. Natural Product Communications 10: 1349-1350.

Li SY, Chang CQ (2005) Biological effects of chlorogenic acid and body health. Wei Sheng Yan Jiu 34: 762-764.

Mondal S, Bhar K, Mahapatra AS, Mukherjee J, Mondal P, Rahman ST, Nair AP (2020) "Haripriya" God's favorite : Anthocephalus cadamba (Roxb.) Miq.-at a glance. Pharmacognosy Research 12: 1-16.

Nagakannan P, Shivasharan BD, Veerapur VP, Thippeswamy BS (2011) Sedative and antiepileptic effects of Anthocephalus cadamba Roxb.in mice and rats. Indian Journal of Pharmacology 43: 699-702.

Negi PS (2012) Plant extracts for the control of bacterial growth: Efficacy, stability and safety issues for food application. International Journal of Food Microbiology 156: 7-17.
Pandey A, Negi PS (2016) Traditional uses, phytochemistry and pharmacological properties of Neolamarckia cadamba: A review. Journal of Ethnopharmacology 181: 118-135.

Patel D, Darji VC, Bariya AH, Patel KR, Sonpal RN (2011) Evaluation of antifungal activity of Neolamarckia cadamba (Roxb.) Bosser leaf and bark extract. International Research Journal of Pharmacy 2: 192-193.

Sahu NP, Koike K, Jia Z, Achari B, Banerjee S, Mandal NB, Nikaido $T$ (2000) Triterpene glycosides from the bark of Anthocephalus cadamba. Journal of Chemical Research 1: 22-23.

Sahu NP, Koike K, Jia Z, Achari B, Banerjee S, Nikaido T (1999) Structures of two novel isomeric triterpenoid saponins from Anthocephalus cadamba. Magnetic Resonance in Chemistry 37: 837-842.

Singh S, Ishar MPS, Saxena AK, Kaur A (2013) Cytotoxic effect of Anthocephalus cadamba Miq. Leaves on human cancer cell lines. Pharmacognosy Journal 5: 127-129.

Sircar NN (1992) Pharmacological basis of Ayurvedic therapy; in cultivation and utilization of medicinal plants. Publication and Information Directorate, CSIR, Delhi, Pp.507-518.

Slkar IV, Kakkar KK, Chakre OJ (1992) Glossary of Indian Medicinal Plants with Active Principles. CSIR, Delhi, Pp. 75.

Verma R, Chaudhary F, Kumar J (2019) Evaluation of antiinflammatory, analgesic and antipyretic properties of Neolamarckia cadamba on Wistar albino rats. Journal of Pharmacology \& Clinical Research 7: 1-5.

Vichai V, Kirtikara K (2006) Sulforhodamine B colorimetric assay for cytotoxicity screening. Nature Protocols 1: 1112-1116. 